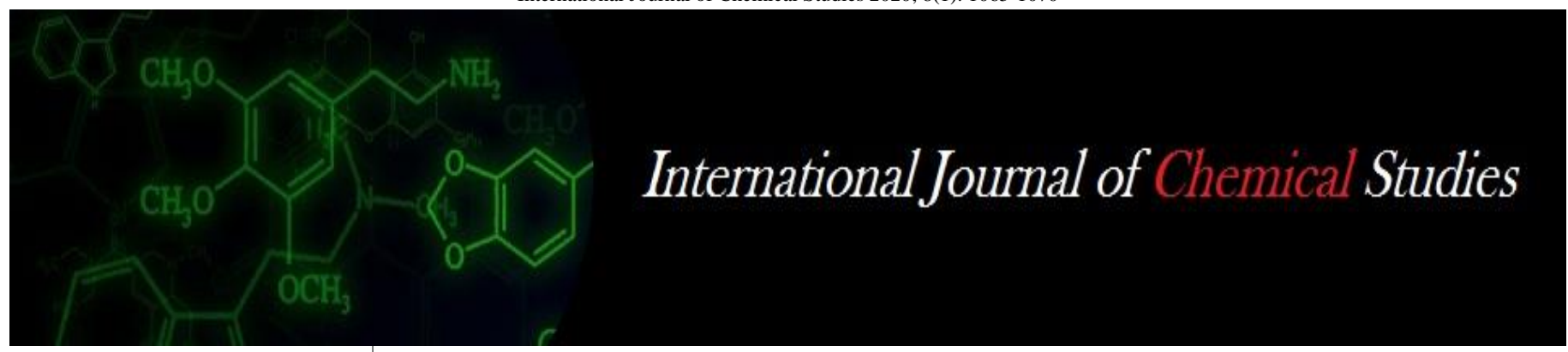

P-ISSN: 2349-8528

E-ISSN: 2321-4902

IJCS 2020; 8(1): 1065-1070

(C) 2020 IJCS

Received: 23-11-2019

Accepted: 26-12-2019

Vinayak Hosamani

P2 Basic Seed Farm, National

Silkworm Seed Organization,

Central Silk Board, Nagenahally,

Kunigal, Karnataka, India

\section{Mallikarjuna Yalagi}

NAHEP Project, University of

Agricultural Sciences, Raichur,

Karnataka, India

Pramod Sasvihalli

SSPC, National Silkworm Seed

Organization, Central Silk

Board, Raiganj, West Bengal,

India

Venkatesh Hosamani

Entomology, COH, Munirabad-

Koppal, Karnataka, India

K Sashindran Nair

National Silkworm Seed

Organization, Central Silk

Board, BTM Layout, Madivala,

Bangalore, Karnataka, India

\section{VK Harlapur}

National Silkworm Seed

Organization, Central Silk

Board, BTM Layout, Madivala,

Bangalore, Karnataka, India

\section{CR Hegde}

Seed Cocoon Procurement

Centre, National Silkworm Seed

Organization, Central Silk

Board, Kunigal, Karnataka,

India

\section{RK Mishra}

National Silkworm Seed

Organization, Central Silk

Board, BTM Layout, Madivala,

Bangalore, Karnataka, India

Corresponding Author:

Vinayak Hosamani

P2 Basic Seed Farm, National

Silkworm Seed Organization,

Central Silk Board, Nagenahally,

Kunigal, Karnataka, India

\section{Sucking pest and their management in mulberry (Morus alba): A review}

\author{
Vinayak Hosamani, Mallikarjuna Yalagi, Pramod Sasvihalli, Venkatesh \\ Hosamani, K Sashindran Nair, VK Harlapur, CR Hegde and RK Mishra
}

DOI: https://doi.org/10.22271/chemi.2020.v8.i1n.8394

\begin{abstract}
Mulberry (Morus spp.) is regarded as a native of Himalayas and is cultivated in more than 32 countries in tropical, subtropical and temperate regions of the world. Mulberry being the sole food plant of mulberry silkworms, the quality, productivity and profitability in commercial sericulture depends on the yield of mulberry. Mulberry crop is considered as only food for the silkworm, Bombyx mori L. which is commercially exploited. It is a perennial, evergreen, luxuriant crop cultivated in all types of soils, both under rainfed and irrigated conditions. The crop is prone to depredation of diverse organisms, because of its fast growth and green foliage throughout the year, in varying proportions either for space, food or both. So far, over 300 insect and non-insect species of pests are known to infest mulberry in varying intensities during different stages of the crop and seasons. The maximum leaf yield potential of mulberry is yet to be trapped under irrigated conditions which are low for various reasons. Of these, improper nutrient management practice, decline in soil fertility status and delayed irrigation (due to failure of rains or canal water) and imbalanced nutrition and non-adaptability of prime production practices and insect pest are major constraints for low leaf productivity. Among the production constraints, sucking pest occurrence has become major problem in mulberry garden cultivation. The pests which are infesting mulberry are categorized into sap suckers, defoliators and root feeders. The sucking pest includes mealy bug, trips, spiralling whitefly, leaf hoppers, jassids and scale insects which cause damage to mulberry crop. Most of the sap sucking insects, such as adult leaf hoppers, aphids or thrips causes minimal direct tissue destruction. These insects use a specialized mouth part, the style, to locate, penetrate and drain sap from the phloem sieve elements of the plants vascular tissue. Majority of the sericulture farmers throughout the country have opined that mulberry (Morus spp.) is very much prone to sucking pest. Now a day's majority of the mulberry cultivars and sericulture farmers have been approaching scientists and extension agencies for efficient control measures of sucking pest of mulberry especially thrips under such condition management of thrips through the eco-friendly approach and giving the crop condition in the parcel basis to the farmers is necessary to increase the mulberry leaf yield. Hence, the review.
\end{abstract}

Keywords: Sericulture, economics, mulberry, cocoon. mulberry pests, crop loss, seasonal incidence, symptoms

\section{Introduction}

Sericulture is a highly labour intensive, remunerative and rural welfare oriented agro based Industry. In the global context, India is the second largest raw silk producing country after China. India has the unique distinction of being the only country in the world to produce all four commercial silks. Silk production has achieved remarkable growth during recent times. Silk production increased from 23,060 MT in 2011-12 to 31906 MT in 2017-18 at a compound growth rate of $5.1 \%$ per annum. Country raw production is expected to reach 38500 MT by 2019-20 and become self-reliant by 2022. The maximum leaf yield potential of mulberry is yet to be trapped under irrigated conditions which are low for various reasons. Of these, improper nutrient management practice, decline in soil fertility status and delayed irrigation (due to failure of rains or canal water) and imbalanced nutrition and non-adaptability of prime production practices and insect pest are major constraints for low leaf productivity. Among the production constraints, sucking pest occurrence has become major problem in mulberry garden cultivation. Majority of the sericulture farmers throughout the country have opined that mulberry (Morus spp.) is very much prone to sucking pest. The quality of mulberry leaf is 
influenced by several factors such as variety, agronomic practices and abiotic components (Krishnaswami et al. 1970)

${ }^{[25]}$. Inspite of all these factors, sometimes, the nutritive values are degraded due to diseases and pest damage. Since mulberry leaf is available throughout the year, it makes the plant prone to various diseases and pests. About 300 insect and non-insect species of pests are known to occur on mulberry. Among the pests few are sap suckers and defoliators. Sucking pests of mulberry is classified as major and minor based on the incidence of pest. Major sucking pests includes mealy bug, thrips and spiraling whitefly and minor includes the jassids, scale insects and non-insect pest is mite.

Mealy bug: The mealy bug is considered as an important cosmopolitan sucking pest and regular in occurrence. This pest is highly prevalent in tropical regions and has a wide range of alternate hosts including ornamental, timber and wild plants. This insect is prevalent as polyphagous. Two species of mealy bug infest the mulberry i.e. Pink mealy bug and papaya mealy bug. The infesting stages are both nymph and adult.

Pink mealy bug: It is native to southern Asia and has spread to other parts of the world like Africa and more recently to North America and Caribbean, (Kairo et al., 2000) ${ }^{[22]}$. In India, the occurrence of this pest was reported in Murshidabad district of West Bengal (Mukerji, 1899) ${ }^{[33]}$.

Crop loss and seasonal incidence: Satyaprasad et al. (2000) ${ }^{[49]}$ reported that, mealy bug incidence caused an estimated loss in leaf yield of $4500 \mathrm{Kg} / \mathrm{ha} / \mathrm{yr}$ (34.24\%) and more than $30 \%$ which sometimes reaches upto $50 \%$ reported by (Vijaya Kumari, 2014). Pink mealy bug caused damage to the mulberry crop throughout the year which was ranged from 0.79 to 11.69 percent and severity was found to be maximum during July to August (Benchamin et al., 1997) ${ }^{[6]}$. High incidence of pink mealybug was noticed in March and reduced in August, the least was in December (Hemalatha and Shree, 2008) ${ }^{[17]}$.

Symptom: Immature and mature mealy bugs are found in clusters on the stalks under overlapping leaf sheath, below the node and spread up and down to the other internodes and buds. The damage mainly occurs by sucking cell sap, depriving plants of essential nutrients, which may lead to stunting, yellowing, and thin canes. The thickened leaves turn dark colour, on severe infestation it leads to short intermodal distance and appears like bunchy top so this disease is also called as tukra disease. During later stage of infestation, sooty mould development takes place due to excretion of honey dew secretion of mealy bug (Govindaiah et al., 2005) ${ }^{[15]}$.

Spiraling whitefly: Spiralling white fly Aleurodicus dispersus Russel was considered as a minor pest in mulberry because its occurrence was occasional and damage was less. But in recent days it has become a major pest causing extensive damage to mulberry in south India. In West Bengal Dialeuropora decempuncta and Aleuroclava pentatuberculata are the major types of white flies which are reported in 1999. Recently, during 2011 severe outbreak of D. decempuncta was reported on mulberry from Wayanad district of Kerala (Josepha et al., 2011) ${ }^{[19]}$. However, during routine survey on insect pests of mulberry, since 2009, the severe infestation of mulberry gardens with $D$. decempuncta in Mandya and
Mysore districts was confirmed. Aleurodicus dispersus is native to the Caribbean islands and Central America.

Crop loss and seasonal incidence: The whiteflies are present throughout the year in south India, with high populations in summer (March-June) and low in winter (October-January) (Vijaya Kumari, 2011) ${ }^{\text {[57]. The whitefly infestation was seen }}$ from February to August (peak) and October to December coinciding with a prolonged dry spell followed by hot humid weather. (Bandopadhyay and Santhakumar, 2000) ${ }^{[5]}$. In the hot spot areas of Mysore and Mandya districts, the incidence ranged from 20 to even above 85\% (Narendra Kumar et al., 2013) ${ }^{[38]}$. Due to whitefly infestation, crop loss in mulberry silkworm rearing was upto $5 \mathrm{~kg}$ cocoons/ $100 \mathrm{dfl}$ (disease free layings) (Yumnam Debaraj et al., 2013) ${ }^{[59]}$.

Symptoms: Adults and nymphs of the whitefly remain in colonies under the surface of leaves. The copious white, waxy, flocculants, material secreted by all the stages of pest is readily spread by wind, causing nuisance (Kumashiro et al., 1983) ${ }^{[26]}$. Spiralling whiteflies feed on plants by sucking plant sap/juices from the phloem through a slender stylet, it results in curling, chlorosis, defoliation and stunted growth. The honey dew excreted by these insects will fall on the upper surface of the lower leaves which becomes a medium for developing-sooty mould\| fungus, Capmodium sp. This in turn, interferes with photosynthetic process by not allowing enough light to reach the cytochrome tissues of the leaves. The sooty mold may also increase thermal absorption and raise leaf temperature, thus in turn reduces leaf efficiency and leads to further deterioration in the nutritional quality (Bryne et al., 1990) ${ }^{[8]}$.

Thrips: Pseudodendrothrips mori was found to be most dominant species in different parts of world. Thrips is considered as a highly oligophagous pest and native of northern hemisphere. Thrips has become a dominant and regular pest of mulberry. About 21 species (46.67\%) of thrips are identified as pest of agricultural crops. Devaiah and Kotikal (1983) [12,13] reported the incidence of thrips on mulberry in Karnataka.

Crop loss and seasonal incidence: High rainfall and humidity were not favourable for thrips resulting in low peaks of thrips population on mulberry (Venugopalapillai and Krishnaswamy 1980). P. mori cause loss in the leaf area and leaf weight resulting in yield reduction to the tune of 20-50 percent (Muthuswami et al., 2010) ${ }^{[35,36]}$. The estimated leaf loss due to this pest is about $40-50 \%$ of the total leaf produced (Mahadeva, 2011) ${ }^{[31]}$.

Symptom: It feeds on fully expanded leaves and young tissue in the bud. Thrips causes a damage on a single leaf blade by using their mouth parts, rasp the epidermis on the ventral side. During laceration, they secret saliva, which coagulates the sap. Leaf forms boat shape and sever infestation leads to chlorosis. Infested leaves dry out and have a stippled or silver flecked appearance. Small brownish specks of excrement are usually noticed on the underside of the leaves. The nymphs and adults of the mulberry thrips lacerate the tissue and suck the oozing cell sap from the upper and lower surfaces of the leaves. So, the usual evaporation process of the leaves is quickened, especially during high temperature seasons, by additional evaporation through these wounds (Mahadeva and Shree, 2014) ${ }^{[30]}$. 
Among the sap feeders infesting mulberry, incidence of thrips is the highest $(42.55 \%)$ followed by mealy bug $(20.80 \%)$, jassids (20.28\%) and scale insect (1.65\%) (Anon., 1993). So far, 35 species of thrips are reported to inflict damage to mulberry all over the world, of which 21 species are from India. In Karnataka four species of thrips viz., Pseudodendrothrips mori (Nawa), Taeniothrips claratris (Shumsher), Taeniothrips glycines (Okomoto) and Haplothrips coloratus (Trylom) are reported to damage mulberry in Karnataka (Devaiah and Kotikal, 1983) [12, 13]. Among the species, Pseudodendrothrips mori comprised of 66.67 percent indicating its dominance over other species of thrips (Manjunath et al., 2001) ${ }^{[32]}$. Thrips menace was very high during the peak silkworm rearing periods (March-April, June-September and November-December). The estimated loss was to the tune of 40-50 percent of the total leaf produced during the seasons, thus causing serious problems to the seriuclturists in southern states of India (Venugopalapillai and Krishnaswami, 1980). Thrips are unique among insects by virtue of their fringed wings, having rasping and sucking type of mouth parts with vestigial right mandible. Thrips feed on fully expanded leaves and young tissue in the bud. Infested leaves dry out and have a stippled or silver flecked appearance. Small brownish specks of excrement will usually be noticed on the underside of the leaves (Lewis, 1997) ${ }^{[28]}$. Thrips damage causes loss of moisture from leaves besides causing appreciable reduction in protein and sugar value of leaves.

\section{Botanical extracts on mulberry thrips and leaf yield}

Rangaswami et al. (1976) ${ }^{[42]}$ reported that sprinkler irrigation was found to be effective in reducing thrips population as a result of washing out of various nymphal stages from the leaves. Somchai et al. (1999) ${ }^{\text {[52] }}$ used insecticides and botanicals viz., carbosulfan (Posse 20 percent EC), fipronil (Ascend 5\% SC), imidacloprid (Admire 5\% EC), dichlorvos (Terra 50\% EC), neem extract $(0.1 \%$ Azadirachtin) and monocrotophos (Azodrin 60\% WSC) at the rate of 30, 10, 10, 20, 100 and $20 \mathrm{ml}$ per 20 liters of water, respectively against mulberry thrips, Pseudodendrothrips ornatissimus Schmutz. The highest percentage of control at 7 days after spray was with monocrotophos $(86.99 \%)$, followed by fipronil $(72.10 \%)$ and neem extract $(65.23 \%)$. The efficiency of carbosulfan, imidacloprid and dichlorvos were less than 50 percent. Ashoka and Patil (2001) ${ }^{[4]}$ reported that neem products reduced thrips populations to the extent of 70-80 percent on mulberry. Shekharappa et al. (2001) ${ }^{[51]}$ found that among plant products, yekki registered minimum of 3.78 thrips per leaf followed by golagalaki after 72 hours of spray on mulberry. Subramanian (2003) ${ }^{[53]}$ studied the management of mulberry thrips Pseudodendrothrips mori (Nawa) by chemical method. The result indicated that three insecticides viz. dichlorvos, triazophos and malathion could reduce thrips population to 2.11 from 10.88/leaf and were significantly superior to endosulfan and three other botanicals. All the three plant products, viz., TNAU neem oil (A), TNAU neem oil (C) and Thuja, though not comparable with three effective insecticides but reduced the population by 60 percent. The results revealed that FORS, neem oil, dimethoate 0.03 percent and endosulfan were significantly effective against both nymphs and adults of $T$. tabaci. Dimethoate 0.03 percent and endosulfan 0.07 percent were equally superior to FORS 2.5 percent and neem oil 1 percent in reducing the populations of nymphs as well as adults during both the seasons. Though FORS and neem oil were inferior to the insecticides, FORS proved superior to neem oil in controlling thrips populations. Hadimani et al. (2006) ${ }^{[16]}$ conducted studies on management of mulberry thrips and opined that spraying mulberry crop with 0.02 percent Nuvan (DDVP) or 0.1 percent Rogar was effective with a safe period of 8 to 10 days. Neem seed kernel extract (NSKE) 5 percent recorded 7.81 thrips per plant and was the next best treatment allowing less thrips to survive. The maximum thrips population was recorded in the plots treated with jathropha leaves extract 2 percent (Sule et al., 2008). Among botanicals, neem oil (3\%) exhibited higher efficacy compared to pongamia oil (3\%). The synergistic effect of dimethoate $(0.05 \%)$ along with neem oil was found effective in reduction of thrips population on mulberry over a prolonged period (Sakthivel and Qardi 2010) ${ }^{[44,45]}$. The order of efficacy of insecticides and botanicals against mulberry thrips were acetamiprid 0.03 percent $>$ thiamethoxam 0.025 percent $>$ dichlorvos 0.076 percent $>$ triazophos 0.04 percent $>$ neem oil 3 percent > pongamia oil 3 percent with a safe period of fifteen to twenty days for insecticides and seven days for botanicals (Subramanian et al., 2010) [35, 36]. Sakthivel et al. (2011) ${ }^{[46]}$ reported that dimethoate was more effective in reducing the population of thrips on second day of treatment followed by dichlorvos and water jetting. Dimethoate exhibited the longest persistency and recorded the highest reduction compared to dichlorvos (10 days) after treatment. More than 50 percent reduction was noticed in water jetting. However, water jetting at 15, 25 and 35 days after pruning was best and on a par with two sprays of dimethoate at 15 and 25 days after pruning. Highest leaf yield was recorded in water jetting than chemical. Jayachandran et al. (2012) ${ }^{[18]}$ studied the bio-efficacy of Calotropis gigantea (L.), Annona squamosa (L.), Leucas aspera (Willd.), Zingiber officinale (Roscoe), Curcuma longa (L.), Allium sativum (L.), Capsicum annum (L.) and Acorus calamus (L.) with cow urine to control Pseudodendrothrips mori (Nawa) and sprayed at different concentrations in comparison with dichlorvos. On 26th day of treatment, the amalgamated plant extract and dichlorvos reduced thrips population up to 95.6 percent and 61.14 percent respectively. Jyothi et al. (2013) [20, 21] evaluated the bioefficacy of eight insecticides viz., spinosad 45 SC, fipronil 5 SC, imidacloprid 17.80 SL, acetamiprid 20 SP, thiamethoxam $25 \mathrm{WG}$, flupyradifurone $20 \mathrm{SL}$, dichlorvos $76 \mathrm{EC}$ and nimbecidine 0.03 percent against mulberry thrips, Pseudodendrothrips mori (Nawa). Among the treatments, fipronil, flupyradifurone, acetamiprid, imidacloprid, thiamethoxam were most effective in reducing the population of thrips to $0.97,0.99,1.03$, and 1.05 to 1.08 per top three leaves respectively at five days of spraying as compared to 15.31 per top three in unsprayed leaves.

\section{Botanical extracts to mulberry silkworms}

Spraying mulberry with dichlorvos $(0.02 \%)$ or rogor $(0.1 \%)$ was effective against thrips with a safety period of three and fifteen days respectively (Anon., 1975) ${ }^{[2]}$. Kariappa and Narasimhanna (1978) [23] worked out the safety period for dichlorvos (Nuvan) and dimethoate (Rogar) was one and five days, respectively. Suhas and Devaiah (1985) ${ }^{[54]}$ reported that dichlorvos $(0.016 \%)$ and neem oil $(5 \mathrm{ml} / \mathrm{l})$ were safe for silkworm feeding 20 hours and seven days after spray. The silkworm mortality and effective rate of rearing were to the tune of 4.9 and 6.35 percent and 91.6 and 89.10 percent, respectively. Sharma (1989) ${ }^{[50]}$ found that dichlorvos at 0.02 percent was effective against thrips with a safe period of three days. Rajadurai et al. (1999) ${ }^{[40]}$ observed that neem seed kernel extract, commercial neem formulation, Rakshak and 
Neem oil were safer to silkworm from six to seven days after spraying. Ashoka and Patil (2001) [4] reported that, the mulberry leaves sprayed with Neemark $(5 \mathrm{ml} / \mathrm{lit})$, Neem oil 0.3 percent ( $5 \mathrm{ml} / \mathrm{lit})$, Neem gold $(5 \mathrm{ml} / \mathrm{lit})$, Rakshak $(5 \mathrm{ml} / \mathrm{lit})$ and Nimbecidine $(5 \mathrm{ml} / \mathrm{lit})$ for the control of mulberry thrips could be safely fed to silkworms three days after spraying. While, oxydemeton methyl $(1.4 \mathrm{ml} / \mathrm{lit})$ sprayed leaves would be safe after seven days. Hadimani et al. (2006) ${ }^{[16]}$ opined that spraying mulberry crop with 0.02 percent dichlorvos (Nuvan) or 0.1 percent dimethoate (Rogar) was effective with a safe period of 8-10 days. Li et al. (2010) ${ }^{[29]}$ used naled 50 $\mathrm{EC}$, dimethoate $40 \mathrm{EC}$ and dichlorvos $80 \mathrm{EC}$ against mulberry thrips in a field trial. The results showed that the pesticides sprayed leaves were safe for silkworms from three days after application.

Subramanian et al. (2010) ${ }^{[35,36]}$ observed the mortality of silkworms on the day of spraying on mulberry of above 90 percent with triazophos $(98.17 \%)$, acetamiprid $(97.15 \%)$, thiamethoxam (96.57\%) and dichlorvos (95.63\%). The percent mortality in neem oil and pongamia oil was 58.71 and 46.56 percent, respectively. All the insecticides and botanicals effected mortality up to fifth day. No mortality was observed on the seventh day for neem oil and pongamia oil on tenth day, dichlorvos, triazophos and thiamethoxam were safer to silkworm on fifteen day, whereas acetamiprid was safer on twentieth day after spraying. Jayachandran et al. (2012) [18] opined that a minimum of ten days were required as safety period to young age silkworms after spraying of indigenously prepared plant extracts of Calotropis gigantean (L.), Annona squamosa (L.), Leucas aspera (Willd.), Zingiber officinale (Roscoe), Curcuma longa (L.), Allium sativum (L.), Capsicum annuum (L.) and Acorus calamus (L.) with cow urine. Jyothi et al. (2013) ${ }^{[20,21]}$ studied the waiting period of insecticides used for mulberry thrips viz., nimbecidine $(0.03 \%)$, dichlorvos (76 EC), fipronil (5 SC), flupyradifurone (20 SL), imidacloprid (17.8 SL), acetamiprid (20 SP), thiamethoxam (25 WG) and spinosad (45 SC) as 7, 9, 11, 15, 15, 21, 21 and 35 days after sprays.

\section{Impact of botanical extract sprayed leaves on rearing performance}

Feeding silkworms with mulberry leaves sprayed with dimethoate after waiting period showed a significant improvement with respect to larval, cocoon and shell weight as compared to the infested control (Kariappa and Narasimhanna, 1978) [23]. Naik et al. (2000) [37] observed minimum young age larval weight when fed on thrips infested leaves compared to silkworms feed with healthy tender mulberry leaves. Significant decrease in total cocoon production, cocoon, pupal and shell weight was observed due to feeding of thrips infested leaves to silkworms (Etebari and Bizhannia, 2006) ${ }^{[14]}$. Mukhopadhyaya et al. (2008) ${ }^{[34]}$ opined that rearing silkworms with neem oil, pongamia oil and nicotine extract sprayed leaves after observing waiting period had no impact on the economic parameters of the cocoon. The mulberry leaves (MR2) sprayed with met-acid was found to inhibit the developmental stages of silkworms at a high level when compared with Neem oil (Kumutha et al., 2009) [27]. Silkworms fed with acetamiprid $(0.03 \%)$ sprayed leaves recorded higher larval, cocoon and shell weight and shell ratio. Dichlorvos $(0.076 \%)$ and triazophos were equally effective, while neem and pongamia (3\%) were on par (Muthuswami et al., 2010) ${ }^{[35,36]}$.

Thus, the foregoing review reveals that the sucking pests especially thrips are most serious and cause injury to apical portion which not only prevent the further growth but also deteriorate the biochemical constituents of leaf which intern affects the production of good quality of raw silk. Since sucking pests cause severe damage to crop, there is a necessary to adopt proper management practices at the right time during the mulberry crop production. Sucking pest results in the reduction of the leaf quantity leading to lower yields; half of the normal yields in uncontrolled situation. The review revealed that among botanicals and insecticide used, dichlorvos 0.02 percent significantly reduced pest population and superior over all treatments. Although dichlorvos was effective over botanicals were comparable, besides the plant growth and leaf quality influenced by spraying botanicals are safe to the natural enemies in mulberry ecosystem and are biodegradable. However, for the management of mulberry sucking pest, neem oil 3 percent and pongamia oil 3 percent could be the next best alternate choice to dichlorvos. Now a day's majority of the mulberry growers in India as well as Karnataka have expressed that mulberry was very susceptible to thrips incidence and also they touching the doors of agriculture university and extension agencies for the reason and efficient control of sucking pest especially dangerous thrips hence, there is a need to intensified research work on finding the exact reason and management of sucking pest and to give the crop condition in parcel basis in necessary.

\section{References}

1. Ali MR, Qaiyyum, Rahman S. Chemical control of mulberry thrips (Taeniothrips sp). Bull. Seric. Res. 1991; $1: 23-25$.

2. Anonymous. Textbook of tropical sericulture. Japan Overseas Co-operation Volunteers, Tokoyo, Japan, 1975, 227-260.

3. Anonymous. Annu. Rep. (2017-18), Seri States of India-a Profile, 2018, 1.

4. Ashoka J, Patil BV. Bio efficacy of neem-based insecticides against mulberry thrips. Proc. Nation. Sem. Mulb. Seri. Res. India., Karnataka State Seri. Res. Dev. Inst., Bangalore, 2001, 820-824.

5. Bandyopadhyay UK, Santhakumar MV. Indian Silk. 2000; 39(7):10-12.

6. Benchamin KA, Venkataramana P, Thimma Naik S, Sanath Kumar YN. Pest and disease occurrence in mulberry and silkworm: A survey. Indian Silk. 1997; 36(2):27-32.

7. Bioefficacy of botanicals and insecticides against mulberry thrips, Pseudodendrothrips mori. Karnataka J Agric. Sci., 23(1):47-50.

8. Bryne DN, Bellows TS, Parella MP. Whiteflies in agricultural system in: Whiteflies-their bionomics, pest status and management. (Eds. Gerling, D and Wimborne) U.K. Intercept, 1990, 227-261.

9. Dandin SB, Jayaswal J, Giridhar K. Hand Book of Sericulture Technologies. Central Silk Board, Bangalore, India, 2000.

10. Das C, Shivanath, Rao KM. An investigation on morphophysiological changes due to thrips infestation in mulberry (Morus alba). Geobios. 1994; 21:109-113.

11. Das C, Shivanath, Sinha SS. Thrips (Tysanoptera) infestation losses in mulberry (Morus alba). Ann. Entomol. 1994; 12:1-4.

12. Devaiah MC, Kotikal YK. Incidence of thrips on mulberry, Morus alba L. under Dharwad condition. Paper presented In: Nat. Sem. Seri. Res. Dev., Central Silk Board, Bangalore, March, 1983, 10-13, 101. 
13. Devaiah MC, Kotikal YK. Incidence of thrips on mulberry, Morus alba L. under Dharwad conditions. Natl. Sem. Silk Res. Dev., Central Silk Board, Bangalore, 1983, 101.

14. Etebari K, Bizhannia AR. Effects of thrips (Pseudodendrothrips mori Nawa) infested mulberry leaves on silkworm growth and commercial cocoon parameters. Caspian J Env. Sci., 2006; 4(1):31-37.

15. Govindaiah, Gupta VP, Sharma DD, Rajadurai S, Nishitha Naik. Mulberry crop protection, Central silk board, 2005, 311-326.

16. Hadimani DK, Amarnath N, Manjula G, Narayanaswamy KC. Management of mulberry thrips. India Silk, 2006, 11-12.

17. Hemalatha, Shree MP. Analysis of the trend of infestation by sap suckers in mulberry (Morus Spp.) crop system. Indian J. Seric. 2008; 47(1):130-132.

18. Jaychandran R, Madeshan G, Lourdu I, Sakthivel N, Seerangan $\mathrm{R}$, Balakrishna $\mathrm{R}$ et al. Bio-efficacy of amalgamated plant extracts against thrips, Pseudodendrothrips mori (Nawa) on mulberry. Acta Biol. Indica. 2012; 1(2):42-45.

19. Josepha AVM, Soudhaminy PV, Balakrishna R. Indian Silk. 2011; 2(8):12-13.

20. Jyothi P, Ashoka J, Bheemanna M, Nagangouda A, Sreenivas AG, Mekali J. Waiting period for insecticides and botanicals used in control of mulberry thrips. Ann. P1. Prot. Sci. 2013; 21(1):42-45.

21. Jyothi P, Ashoka J, Bheemanna M, Sreenivas AG, Nagangouda A, Narayana Rao K et al. Management of thrips, Pseudodendrothrips mori (Nawa) using insecticides and botanical (Nimbicidine). J Ent. Res., 2013; 37(3):207-209.

22. Kairo MTK, Pollard GV, Peterkin DD, Lopez VF. Biological control of the hibiscus mealy bug, Maconellicoccus hirsutus Green (Hemiptera: Pseudococcidae) in the Caribbean. Integr. Pest Manage. Rev. 2000; 5:241-254.

23. Kariappa BK, Narasinhanna MN. Effect of insecticides in controlling mulberry thrips and their effect on rearing silkworm, Bombyx mori L. Indian J Seric. 1978; 17(1):714.

24. Kasiviswanathan K, Iyengar SHN. Effect of plant densities, method of leaf yield and nitrogen fertilization on leaf yield of irrigated mulberry in Mysore state. Indian J Seric. 1966; 9(1):43-48.

25. Krishnaswami S, Noamani MKR, Ahsan M. Studies on the quality of mulberry leaves and silkworm crop production, Part-I, quality differences due to varieties. Indian J. Seric. 1970; 9(1):1-10.

26. Kumashiro BR, Lai PY, Funasaki GY, Teramoto KK. Efficacy of Nephaspis amnicola and Encaria haitiensis in controlling Aleurodicus disperses in Hawaii. Proceedings of hawaiian entomology society. 1983; 24:261-270.

27. Kumutha PC, Padmalatha S, Doss SM, Ranjit Singh AJA. Toxicology evaluation of neem oil and metacid on the development of the silkworm, Bombyx mori L. Uttrar Pradesh J Zool. 2009; 29(4):220-222.

28. Lewis $\mathrm{T}$. Thrips as crop pests. CAB international publication, 1997, 740.

29. Li H, Huang W, Xie J, Qin B, Wei R. Three organophosphate insecticides on mulberry thrips control and their residual toxicities on silkworm. The Institute for the Control of Agrochemicals of Guangxi, Nanning 530022, China; 2. Guangxi Tianyuan Biochemistry Co.,
Ltd., Nanning 530007, China; 3. Yizhou Plant Protection Station, Yizhou 546300, Guangxi, China, 2010.

30. Mahadeva A, Shree MP. Evaluation of macro and micro nutritive elemental levels in the mealy bug (Maconellicoccus hirsutus) infested leaves of mulberry (Morus sp.). J Plant Nutrition. 2014; 38(1):96-107

31. Mahadeva A. Influence of thrips (Pseudodendrothrips mori) infestation on the biochemical constituents and photosynthetic pigments of mulberry (Morus sp) leaves. International journal of plant, animal and environmental sciences. 2011; 1(3):57-63.

32. Manjunath DV, Jayaramaiah M, Reddy DNR, Narayanaswamy KC, Seenappa K, Jagadish KS. Species composition of thrips and their seasonal incidence on mulberry. Proc. Nat. Sem. Mulb. Seric. Res. India, Karnataka State Seri. Res. Dev. Inst., Bangalore, 2001, 837-843.

33. Mukerji. Handbook of Sericulture. Bengal Secretariat Press, Calcutta, 1899, 121-127.

34. Mukhopadhyaya SK, Santha Kumar MV, Das MPSK, Bajpai AK. Botanical mediated control of whitefly in mulberry and their impact on leaf yield and silkworm rearing. In: Insect Pest Management and Environment Safety Support. Ed S. C. Goel Uttar Pradesh Zoological Society, Muzaffarnagar, India, 2008, 233-38.

35. Muthuswami M, Indumathi P, Krishnan R, Thangamalar A, Subramanian S. Impact of chemicals used for thrips control on silkworm, Bombyx mori L. Karnataka J Agric. Sci. 2010; 23(1):144-145.

36. Muthuswami M, Subramanian S, Krishnan R, Thangamalar A, Indumathi P. Quantitative and qualitative damage caused in mulberry varieties due to infestation of thrips Pseudodendrothrips mori Niwa. Karnataka J Agric. Sci. 2010; 23(1):146-148.

37. Naik SL, Reddy DNR, Sannappa B. Feeding thrips infested mulberry leaves and its effect on the growth of young age silkworm, Bombyx mori. Karnataka J Agric. Sci. 2000; 13(1):190-193.

38. Narendra Kumar JB, Sreenivas BT, Divya SH, Shekhar MA. New White fly species Dialeuropora decempuncta Quaintance (Homoptera: Aleyrodidae) infesting mulberry in Karnataka. Insect Environment. 2013; 19(2):108-109.

39. Rajaduari MM, Thiagarajan V. Mulberry sap sucking pests. Indian Silk. 2003; 8:5-8.

40. Rajadurai S, Manjunath D, Katiyar RL, Prasad KS. Leaf roller-A serious pest of mulberry. Indian Silk. 1999; 37(12):9-12.

41. Ramrao. Bioefficacy of Phyto formulations against mulberry thrips, Pseudodendrothrips mori (Nawa) and their effect on mulberry and silkworms. M. Sc. (Agri) Thesis, Univ. of Agric. Sci., Dharwad, 2014.

42. Rangaswami G, Narasimhanna MN, Kasiviswanathan K, Sastry CR. Manual on sericulture-1. Mulberry cultivation. FAO, Agricultural service Bulletin, 15/1, Rome, 1976, 150.

43. Reddy DNR, Kotikal YK. Pests of mulberry and their management, Indian Silk. 1988; 10(3):9-15.

44. Sakthivel N, Qadri SMH. Impact of insecticides and botanicals on population build-up of predatory coccinellids in mulberry. J Biopest. 2010; 3(1):85-87.

45. Sakthivel N, Qadri SMH. Efficacy of certain insecticides and botanicals against mulberry thrips, Pseudodendrothrips mori Nawa (Thysanoptera: Thripidae). Indian J Entomol. 2010; 72(2):152-15. 
46. Sakthivel N, Balakrishna R, Qadri SMH. Comparative efficacy of water jetting and chemical measures against major sucking insects of mulberry and their safety to natural enemies. J Bioinsecticides. 2011; 4(2):219-230.

47. Sakthivel N, Balakrishna R, Ravikumar J, Samuthiravelu $\mathrm{P}$, Isaiarasu L, Qadri SMH et al. Efficacy of botanicals against jassid, Emposca flavescens F. (Homoptera: Cicadellidae) on mulberry and their biosafety to natural enemies. J Biopest. 2012; 5:246-249.

48. Sathyaprasad K, Manjunath D. Monitoring the incidence of pests of mulberry. Annu. Rep. Centl. Seri. Res. and Trg. Inst., Mysore, 1993, 39.

49. Sathyaprasad K, Manjunath D, Rajan MV, Sarkar A. Screening of mulberry germplasm for tolerance to sucking pest. Abs. Ntnl. Con. Str. for seri. Res. dev. CSR \& TI, Mysore. 2000; 1:7.

50. Sharma PP. Insect pests of Sericulture and their control. Pesticides. 1989; 23(12):19-23.

51. Shekharappa Rayar SG, Patil RK. Evaluation of plant products in the management of mulberry thrips, Pseudodendrothrips mori (Thysanoptera: Thripidae). Karnataka J Agric. Sci. 2001; 14(3):811-812.

52. Somachai S, Sahaya S, Kesara J, Mallika K. Efficacy test of insecticides for controlling mulberry thrips, Pseudodendrothrips ornatissimus Schmutz in mulberry field. Department of Agriculture, Bangkok (Thailand). Entomology and Zoology Div. Cotton and Fiber Crops Entomology Research group, 1999.

53. Subramanian A. Management of mulberry thrips, Pseudodendrothrips mori by chemical method. Madras Agric. J. 2003; 90(10-12):746-748.

54. Subramanian S, Muthuswami M, Krishnan R, Thangamalar A, Indumathi P, Suhas, Y. Studies on the effect of insecticides sprayed mulberry leaves to silkworm, Bombyx mori L. Pesticides. 1985; 19:53-57.

55. Venugopalapillai S, Krishnaswami S. Population of mulberry thrips, Pseudodendrothrips mori (Niwa) in relation to weather factors. Indian J Seric. 1983; 21:4652.

56. Venugopalpillai S, Krishnaswami S. Population of mulberry thrips, Pseudodendrothrips mori (Nawa) in relation to weather parameters. Indian J Seric. 1983; 22:48-52.

57. Vijaya Kumari N. Eco-friendly Technologies for Disease and Pest Management in Mulberry-A Review. Journal of Agriculture and Veterinary Science. 2011; 7(2):1-6.

58. Yey B, Guz F. Chemical control of the mulberry thrips, Pseudodendrothrips mori (Nawa). Sericologia. 1990; 30(3):389-392.

59. Yumnam Debaraj, Gogo SN, Biswas TK, Bindroo BB. New record of a natural enemy on mulberry white fly, Dialeuropora decempuncta (Quaintance \& baker) in Assam. Mun. Ent. Zool. 2013; 8(2):902-904. 